\title{
UPAYA MENINGKATKAN KEMAMPUAN KOMUNIKASI MATEMATIS SISWA KELAS XII MIPA SMA NEGERI 1 SAKRA MELALUI PEMBELAJARAN KOOPERATIF TIPE THINK TALK WRITE
}

\author{
MUHAMMAD NASIR \\ mohnasir1961@gmail.com \\ SMA NEGERI 1 SAKRA
}

\begin{abstract}
ABSTRAK
Tujuan dalam penelitian ini adalah Untuk meningkatkan kemampuan komunikasi matematis siswa Kelas XII MIPA SMA Negeri 1 Sakra melalui pembelajaran kooperatif tipe Think Talk Write (TTW) dan Guru Mampu menerapkan Pembelajaran Kooperatif Tipe Think Talk Write (TTW) dalam Kegiatan Belajar Mengajar (KBM). Penelitian ini merupakan penelitian tindakan kelas (classroom action research). Penelitian tindakan dalam bidang pendidikan yang dilaksanakan dalam kawasan kelas dengan tujuan untuk memperbaiki dan meningkatkan kualitas pembelajaran. PTK ini dilaksanakan dalam 2 siklus. Berdasarkan hasil tes, observasi dan analisis data serta pembahasan dalam penelitian diperoleh hasil: 1) Nilai rata-rata tes pada siklus I sebesar 58,64 dan siklus II sebesar 68,75 . Persentase ketuntasan kelas pada siklus I sebesar $27,78 \%$ dan siklus II sebesar $62,50 \%$. Hal ini menunjukkan bahwa kemampuan komunikasi matematis siswa secara tertulis mengalami peningkatan namun belum mencapai indikator yang ditentukan. 2) Skor rata-rata total kemampuan komunikasi matematis siswa secara lisan pada siklus I sebesar 2,43 dengan kategori cukup baik dan siklus II sebesar 2,98 dengan kategori baik. Hal ini menunjukkan bahwa kemampuan komunikasi matematis siswa secara lisan mengalami peningkatan dan sudah mencapai indikator yang ditentukan. 3) Skor rata-rata total hasil pengamatan KBM pada siklus I sebesar 2,70 dengan kategori baik dan siklus II sebesar 3,15 dengan kategori baik. Hal ini menunjukkan bahwa kemampuan guru dalam menerapkan pembelajaran kooperatif tipe think talk write (TTW) mengalami peningkatan dan sudah mencapai indikator yang ditentukan. 4) Pembelajaran kooperatif tipe Think Talk Write (TTW) mampu meningkatkan kemampuan komunikasi matematis siswa namun peningkatannya belum optimal.
\end{abstract}

Kata Kunci : Pembelajaran Kooperatif Think Talk Write Komunikasi Matematis

\begin{abstract}
The purpose of this study is to improve the mathematical communication skills of Class XII MIPA students of SMA Negeri 1 Sakra through cooperative learning of Think Talk Write (TTW) type and teachers are able to apply Think Talk Write (TTW) Cooperative Learning in Teaching and Learning Activities (KBM). This research is a classroom action research (classroom action research). Action research in the field of education carried out in the classroom area with the aim of improving and improving the quality of learning. This CAR is carried out in 2 cycles. Based on the results of tests, observations and data analysis as well as discussions in the study, the results obtained: 1) The average value of the test in the first cycle is 58.64 and the second cycle is 68.75 . The percentage of class completeness in the first cycle was $27.78 \%$ and the second cycle was $62.50 \%$. This shows that students' written mathematical communication skills have increased but have not yet reached the specified indicators. 2) The total average score of students' verbal mathematical communication skills in the first cycle was 2.43 with a good enough category and 2.98 in the second cycle with a good category. This shows that students' verbal mathematical communication skills have increased and have reached the specified indicators. 3) The total average score of the results of KBM observations in the first cycle is 2.70 in the good category and the second cycle is 3.15 in the good category. This shows that the teacher's ability to implement think talk write (TTW) cooperative learning has increased and has reached the specified indicators. 4) Think Talk Write (TTW) cooperative learning is able to improve students' mathematical communication skills but the increase is not optimal.
\end{abstract}

Keywords: Cooperative Learning Think Talk Write Mathematical Communication 


\section{PENDAHULUAN}

Dalam rangka meningkatkan sumber daya manusia yang berkualitas diperlukan strategi pembelajaran yang diharapkan mampu memperbaiki sistem pendidikan yang telah berlangsung selama ini. Salah satu tolok ukur keberhasilan guru adalah bila dalam pembelajaran mencapai hasil yang optimal. Keberhasilan ini sangat dipengaruhi oleh kemampuan guru untuk mengelola proses belajar mengajar.

Tujuan pembelajaran matematika di sekolah agar siswa memiliki kompetensi untuk melanjutkan studi ke jenjang pendidikan yang lebih tinggi dan untuk memecahkan masalah dalam kehidupan sehari-hari. (Kompetensi atau kecakapan matematika yang diharapkan dapat tercapai melalui pembelajaran matematika tertuang dalam Permendiknas No. 22 tahun 2006 tentang standar isi). Disini dinyatakan bahwa tujuan pelajaran matematika di SD/MI SMP/MTs, SMA/MA, dan SMK/MAK adalah diantaranya agar peserta didik: 1) Memahami konsep matematika, menjelaskan keterkaitan antar konsep dan mengaplikasikan konsep atau algoritma, secara luwes, akurat, efisien, dan tepat dalam pemecahan masalah; 2) Menggunakan penalaran pada pola dan sifat, melakukan manipulasi matematika dalam membuat generalisasi, menyusun bukti, atau menjelaskan gagasan dan pernyataan matematika; 3) Memecahkan masalah yang meliputi kemampuan memahami masalah, merancang model matematika, menyelesaikan model, dan menafsirkan solusi yang diperoleh; 4) Mengkomunikasikan gagasan dengan simbol, tabel, diagram, atau media lain untuk memperjelas keadaan atau masalah; 5) Memiliki sikap menghargai kegunaan matematika dalam kehidupan, yaitu memiliki rasa ingin tahu, perhatian, dan minat dalam mempelajari matematika, serta sikap ulet dan percaya diri dalam pemecahan masalah.

Dari uraian diatas, komunikasi matematis sangatlah penting tetapi kenyataannya kemampuan siswa dalam komunikasi matematis masih jauh dari yang diharapkan. Hal ini sejalan dengan hasil wawancara yang dilakukan peneliti dengan guru matematika Kelas XII IPA di SMA Negeri 1 Sakra Lalu Wira Janep dan dari pengalaman peneliti selama melaksanakan Pembelajaran di Kelas XII MIPA SMA Negeri 1 Sakra pada 23 Oktober 2020. Dari Wawancara, peneliti memperoleh informasi bahwa kemampuan siswa dalam berkomunikasi matematis masih jauh dari apa yang diharapkan. Salah satunya penyebabnya adalah gaya guru dalam mengajar. Guru lebih memfokuskan pada konsep-konsep matematika. Di dalam kelas, guru biasanya memulai proses pembelajaran dengan menjelaskan konsep matematika, memberikan contoh bagaimana mengerjakan suatu soal, kemudian meminta siswa untuk mengerjakan soal yang sejenis dengan soal yang sudah diterangkan oleh guru. Sedangkan dari pengalaman peneliti selama melaksanakan pembelajaran, pembelajaranan dilakasanakan dengan cara memberi permasalahan matematika yang kemudian diselesaikan secara mandiri oleh siswa. Setelah itu, siswa mempresentasikan jawaban dari permasalahan tersebut. Guru dan siswa mengevaluasi jawaban yang dipresentasikan. Guru memperbaiki jawaban yang salah dan siswa menuliskan kembali jawaban yang sudah benar. Setelah itu meminta siwa mengerjakan soal sejenis dengan soal yang sudah diterangkan sebelumnya namun hasilnya kurang memuaskan. Siswa terlihat mengalami kesulitan dalam mengkomunikasikan simbol-simbol, gambar, grafik, diagram dan kurva kedalam model matematika. Siswa hanya bisa menemukan model matematika setelah adanya contoh yang sejenis dengan permasalahan yang dikerjakan oleh siswa pada proses pembelajaran berlangsung. Terlihat bahwa siswa tidak bisa menyelesaikan masalah matematika dengan tanpa adanya bantuan guru. Jadi, proses pembelajarannya masih didominasi model pembelajaran yang hanya berpusat pada guru. Selain itu, selama peneliti melaksanakan ulangan harian dalam pembelajaran, terdapat beberapa masalah dalam penyelesaian soal ulangan harian yang diantaranya siswa tidak dapat menuliskan langkah-langkah penyelesaian dengan sistematis, hanya menuliskan jawaban tetapi tidak menuliskan langkah penyelesaian, dan tidak bisa mengaitkan beberapa konsep matematika untuk mengerjakan soal ulangan harian. Soal ulangan harian yang dibuat oleh peneliti dalam pembelajaran hampir mirip dengan semua contoh soal yang sejenis yang pernah diajarkan sehingga dalam hal ini diharapkan siswa dapat memperoleh nilai $\geq 76$, namun kenyataannya dari 20 siswa hanya terdapat 9 siswa yang telah mencapai nilai tersebut.

Permasalahan tersebut diperkirakan dapat diatasi dengan menerapkan model yang 
tepat. Model yang diharapkan dapat meningkatkan kemampuan komunikasi matematis siswa adalah model pembelajaran kooperatif tipe Think Talk Write (TTW). Dalam model pembelajaran ini, siswa diberikan waktu untuk melakukan kegiatan berpikir, menyusun ide-ide atau gagasan dan kemudian menuliskannya.

\section{B. Rumusan Masalah}

Berdasarkan latar belakang permasalahan diatas, maka rumusan masalah yang diajukan dalam penelitian ini adalah: Bagaimana upaya meningkatkan kemampuan komunikasi matematis siswa Kelas XII MIPA SMA Negeri 1 Sakra melalui pembelajaran kooperatif tipe Think Talk Write?

\section{Tujuan Perbaikan}

Berdasarkan rumusan masalah diatas, adapun tujuan perbaikan dalam penelitian ini adalah sebagai berikut:

1. Untuk Siswa

Untuk meningkatkan kemampuan komunikasi matematis siswa Kelas XII MIPA SMA Negeri 1 Sakra melalui pembelajaran kooperatif tipe Think Talk Write (TTW).

2. Untuk Guru

Mampu menerapkan Pembelajaran Kooperatif Tipe Think Talk Write (TTW) dalam Kegiatan Belajar Mengajar (KBM).

\section{KAJIAN PUSTAKA}

\section{A. Penelitian Tindakan Kelas (PTK)}

1. Pengertian Penelitian Tindakan Kelas Mc Niff dalam Suroso (2009:19) PTK merupakan bentuk penelitian reflektif yang dilakukan oleh guru sendiri yang hasilnya dapat dimanfaatkan sebagai alat untuk pengembangan kurikulum, pengembangan sekolah, keahlian mengajar dan sebagainya. Menurut Carr dan Kemis hakikat Penelitian Tindakan Kelas (PTK), dalam Kusumah Wijaya dan Dedi Dwitagama (2009:8) adalah suatu bentuk penelitian refleksi diri (Self reflective) yang dilakukan oleh para partisipan dalam situasi sosial untuk memperbaiki nasionalitas dan kebenaran yaitu: (a) praktik-praktik sosial atau pendidikan yang dilakukan sendiri, (b) pengertian mengenai praktik-praktik tersebut, (c) situasi-situasi dan praktikpraktik yang dilaksanakan.

Dalam PTK guru dapat meneliti sendiri terhadap praktik pembelajaran yang dilakukan di kelas. Dengan Penelitian tindakan kelas, guru dapat melakukan penelitian terhadap siswa dilihat dari aspek interaksinya dalam proses pembelajaran dan guru dapat memperbaiki praktik-praktik pembelajaran menjadi lebih efektif. PTK juga dapat menjembatani kesenjangan antara teori dan praktik pendidikan. Hal ini terjadi karena seteleh meneliti kegiatannya sendiri dengan melalui tindakan-tindakan yang sudah direncanakan, dilaksanakan, dan dievaluasi, guru akan memperoleh umpan balik yang sistematik mengenai apa yang selama ini selalu dilakukan dalam kegiatan belajar mengajar. Dengan demikian, guru dapat membuktikan apakah suatu teori belajar mengajar dapat diterapkan dengan baik dikelas yang ia miliki.

Dari uraian diatas Suroso (2009:20) mendefinisikan PTK sebagai suatu bentuk penelitian yang bersifat reflektif dengan melakukan tindakan- tindakan tertentu agar dapat memperbaiki atau meningkatkan praktik- praktik pembelajaran di kelas secara lebih professional.

\section{Karakteristik Penelitian Tindakan} Kelas (PTK)

Menurut Suroso (2009:21), adapun karakteristik Penelitian

Tindakan Kelas (PTK) adalah sebagai berikut:

a. Dari segi problema yang ingin dipecahkan, PTK memiliki karakteristik bahwa problem yang diangkat dari persoalan praktik pembelajaran yang dihadapi guru.

b. Guru dapat duduk bersama, berdiskusi untuk mencari dan merumuskan persoalan pembelajaran di kelas.

c. Adanya tindakan-tindakan (aksi) tertentu untuk memperbaiki proses belajar mengajar di kelas.

Sedangkan menurut Masnur Muslich (2013:12-14), karakteristik

Penelitian Tindakan Kelas (PTK) adalah sebagai berikut:

a. Masalah PTK berawal dari Guru

b. Tujuan PTK adalah memperbaiki pembelajaran

c. PTK adalah penelitian yang bersifat kolaboratif

d. PTK adalah jenis penelitian yang memunculkan adanya tindakan tertentu untuk memperbaiki proses belajar mengajar di kelas

e. PTK dapat menjembatani kesenjangan antara teori dan praktik pendidikan. 3. Langkah-langkah Penelitian Tindakan Kelas (PTK) 
Menurut Wijaya Kusumah dan Dedi Dwitagama (2009:39), langkahlangkah PTK adalah sebagai berikut:

a. Perencanaan

Penentuan perencanaan dapat dibagi menjadi dua jenis, yaitu perencanaan umum dan perencanaan khusus. Perencanaan umum dimaksudkan untuk menyusun rancangan yang meliputi keseluruhan aspek yang terkait PTK. Sementara itu, perencanaan khusus dimaksudkan untuk menyusun rancangan dari siklus ke siklus. Oleh karenanya dalam perencanaan khusus tiap kali terdapat perencanaan ulang (replanning). Hal-hal yang direncanakan diantaranya terkait dengan pendekatan pembelajaran, metode pembelajaran, teknik atau strategi pembelajaran., media dan materi pembelajaran, dan sebagainya. Perencanaan dalam hal ini kurang lebih hampir sama dengan apabila kita menyiapkan suatu kegiatan belajar-mengajar. Biasanya perencanaan dimaksukkan ke dalam rencana pelaksanaan pembelajaran (RPP) dan juga dimasukkan ke dalam silabus mata pelajaran yang bersangkutan.

b. Tindakan

Implementasi tindakan pada prinsipnya merupakan relasi dari suatu tindakan yang sudah direncanakan sebelumnya. Strategi apa yang digunakan, materi apa yang di ajarkan atau dibahas dan sebagainya, PTK bersifat emansifatoris dan membebaskan (Liberating), karena mendorong kebebasan guru dalam berpikir dan beragumentasi dalam bereksperimen, meneliti, dan mengambil keputusan atau judgment.

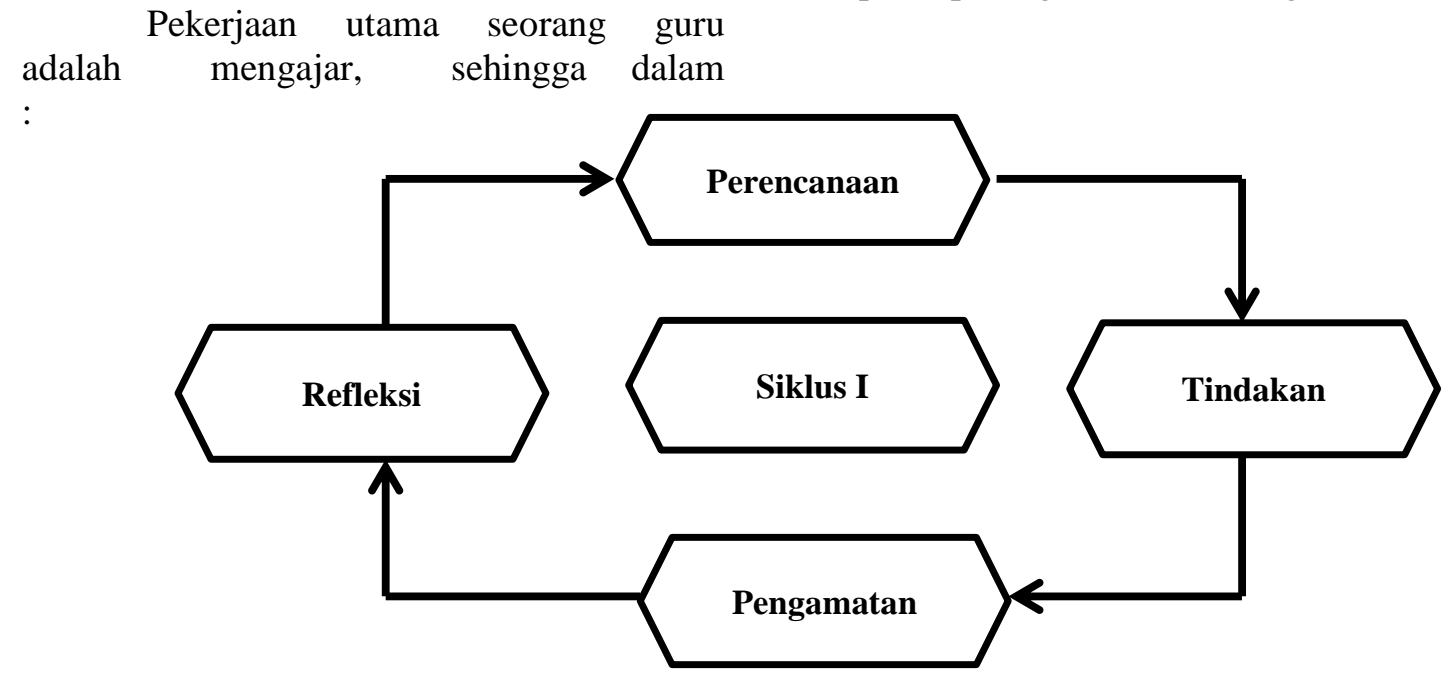

Gambar 2.1 Model PTK Kurt Lewin Hasil Modifikasi Kusumah dan Dwitagama. melakukan PTK seyogyanya tidak berpengaruh pada komitmennya sebagai pengajar. Adanya kebebasan dalam PTK di sekolah justru harus menyulut guru melakukan inovasi dalam proses pembelajarannya di kelas dalam rangka meningkatkan kualitas pendidikan.

c. Pengamatan

Pengamatan, observasi atau monitoring dapat dilakukan sendiri oleh peneliti atau kolaborator, yang memang diberi tugas untuk hal itu. Pada saat monitoring pengamat haruslah mencatat semua peristiwa atau hal yang terjadi di kelas penelitian. Misalnya mengenai konerja guru, situasi kelas, perilaku dan sikap siswa, penyajian atau pembahasan materi, penyerapan siswa terhadap materi yang diajarkan, dan sebagainya.

d. Refleksi

Pada prinsipnya yang dimaksud dengan istilah refleksi ialah perbuatan merenung atau memikirkan sesuatu atau upaya yang dilakukan oleh para kolaborator atau partisipan yang terkait dengan suatu PTK yang dilaksanakan. Refleksi ini dilakukan dengan kolaboratif, yaitu adanya diskusi terhadap berbagai masalah yang terjadi di kelas penelitian. Dengan demikian refleksi dapat ditentukan sesudah adanya implementasi tindakan dan hasil observasi. Berdasarkan refleksi ini pula suatu perbaikan tindakan (replanning) selanjutnya ditentukan. Menurut Kusumah dan Dwitagama (2009:26) untuk melakukan PTK selalu menggunakan empat langkah diatas. Keempat langkah dalam setiap siklus dapat dapat digambarkan sebagai berikut 


\section{Pembelajaran Kooperatif (Cooperative Learning)}

\section{Pengertaian Pembelajaran Kooperatif} Menurut Suprijono (2013:5455) pembelajaran kooperatif adalah konsep yang lebih luas meliputi semua jenis kerja kelompok termasuk bentukbentuk yang lebih dipimpin oleh guru atau diarahkan oleh guru. Secara umum pembelajaran kooperatif dianggap lebih disarankan oleh guru, dimana guru menetapkan tugas dan pertanyaanpertanyaan serta menyediakan bahanbahan dan informasi yang dirancang untuk membantu peserta didik menyelesaikan masalah yang dimaksud. Guru bianya menetapkan bentuk ujian tertentu pada akhir tugas.

Menurut Huda (2013:32-33) pembelajaran kooperatif bergantung pada efektivitas kelompok-kelompok siswa. Masing-masing anggota kelompok bertanggung jawab mempelajari apa yang disajikan dan membantu teman-teman satu anggota untuk mempelajarinya juga. Singkatnya, pembelajaran kooperatif mengacu pada metode pembelajaran di mana siswa bekerja sama dalam kelompok kecil dan saling membantu dalam belajar. Pembelajaran kooperatif umumnya melibatkan kelompok yang terdiri dari 4 siswa dengan kemampuan yang berbeda dan ada pula yang menggunakan kelompok dengan ukuran yang berbeda. Pembelajaran kooperatif biasanya menempatkan siswa dalam kelompokkelompok kecil selama beberapa minggu atau bulan ke depan untuk kemudian diuji secara individual pada ujian yang telah ditentukan. Sebelumnya, kelompok- kelompok siswa ini diberikan pernjelasan/pelatihan tentang: (1) bagaimana menjadi pendengar yang baik, (2) bagaimana memberi penjelasan yang baik, (3) bagaimana mengajukan pertanyaan yang baik, dan (4) bagaimana saling membantu dan menghargai satu sama lain dengan caracara yang baik pula. Dalam lingkungan pembelajaran kooperatif, siswa harus menjadi partisipan aktif dan melalui kelompoknya, dapat membangun komunitas pembelajaran (learning community) yang saling membantu antarsatu sama lain.

\section{E. Pembelajaran Kooperatif Tipe Think Talk Write (TTW)}

1. Pengertian

Model pembelajaran kooperatif tipe Think Talk Write (TTW) diperkenalkan oleh Huinker \& Laughlin. Pada dasarnya pembelajaran ini dibangun melalui proses berpikir, berbicara dan menulis. Strategi pembelajaran Think Talk Write (TTW) dapat menumbuh kembangkan kemampuan pemecahan masalah (Yamin dan Ansari, 2012: 84). Alur kemajuan pembelajaran TTW dimulai dari keterlibatan siswa dalam berpikir atau berdialog dengan dirinya sendiri setelah proses membaca, selanjutnya berbicara dan membagi ide dengan temannya sebelum menulis. Aktivitas berpikir, berbicara dan menulis ini adalah salah satu bentuk aktivitas belajar mengajar yang memberikan peluang kepada siswa untuk berpartisipasi aktif. Tahapantahapan yang dilakukan dalam pembelajaran menggunakan tipe ini adalah berpikir (Think), berbicara (Talk), dan menulis (Write).

a. Berpikir (Think)

Aktivitas berpikir dalam pembelajaran, terdapat dalam kegiatan yang dapat memancing siswa untuk memikirkan sebuah permasalahan baik dalam eksperimen, kegiatan demonstrasi yang dilakukan oleh guru atau siswa, pengamatan gejala fisis atau berbagai peristiwa dalam kehidupan sehari-hari. Proses membaca buku paket matematika serta berbagai macam artikel yang berhubungan dengan pokok bahasan. Setelah itu siswa mulai memikirkan solusi dari permasalahan tersebut dengan cara menuliskannya di buku catatan atau handout atau pun mengingat bagian yang dipahami serta yang tidak dipahaminya.

b. Berbicara (Talk)

Siswa melakukan komunikasi dengan teman menggunakan kata-kata dan bahasa yang mereka pahami. Siswa menggunakan bahasa untuk menyajikan ide kepada temannya, membangun teori bersama, sharing strategi solusi dan membuat definisi.

Talking membantu guru mengetahui tingkat pemahaman siswa dalam belajar sehingga 
dapat mempersiapkan perlengkapan pembelajaran yang dibutuhkan. Fase berkomunikasi (talk) ini juga memungkinkan siswa untuk terampil berbicara. Secara alami dan mudah proses komunikasi dapat dibangun di kelas dan dimanfaatkan sebagai alat sebelum menulis.

Selain itu, berkomunikasi dalam suatu diskusi dapat membantu kolaborasi dan meningkatkan aktivitas belajar dalam kelas. Selanjutnya, berbicara baik antar siswa maupun dengan guru dapat meningkatkan pemahaman. Hal ini bisa terjadi karena saat siswa diberi kesempatan untuk berbicara atau berdialog, sekaligus merekonstruksi berbagai ide untuk dikemukakan melalui dialog.

c. Menulis (Write)

Siswa menuliskan hasil diskusi atau dialog pada lembar kerja yang disediakan. Aktivitas menulis berarti merekonstruksi ide, karena setelah berdiskusi atau berdialog antar teman dan kemudian mengungkapkannya melalui tulisan. Aktivitas menulis akan membantu siswa dalam membuat hubungan dan juga memungkinkan guru melihat pengembangan konsep siswa.

Menurut Yamin dan Ansari (2012:88) aktivitas siswa selama fase ini adalah :

1) Menulis solusi terhadap masalah atau pertanyaan yang diberikan termasuk perhitungan,

2) Mengorganisasikan semua pekerjaan langkah demi langkah baik penyelesaiannya ada yang menggunakan diagram, grafik, atau pun tabel agar mudah dibaca dan ditindaklanjuti,

3) Mengoreksi semua pekerjaan sehingga

yakin tidak ada pekerjaan atau pun perhitungan yang ketinggalan, 4)

Meyakini bahwa pekerjaannya yang terbaik yaitu lengkap, mudah dibaca dan terjamin keasliannya.

Dari uraian di atas dapat disimpulkan bahwa model pembelajaran kooperatif tipe Think Talk Write (TTW) adalah suatu model pembelajaran dengan alur yang dimulai dari keterlibatan siswa dalam berpikir (think) atau berdialog dengan dirinya sendiri setelah proses membaca, selanjutnya berbicara (talk) dan membagi ide (sharing) dengan temannya sebelum menulis (write).

\section{Manfaat Model Pembelajatan Kooperatif Tipe Think Talk Write (TTW)}

Menurut Yamin dan Ansari dalam (2012:84-86) Strategi pembelajaran Think Talk Write (TTW) memiliki manfaat sebagai berikut:

a. Aktivitas think dapat meningkatkan keterampilan siswa dalam membedakan dan mempersatukan ide yang disajikan dalam teks bacaan melalui aktivitas membaca terlebih dahulu.

b. Pembentukan ide dapat dilakukan melalui talking.

c. Pemahaman matematik di bangun melalui interaksi dan konversasi (percakapan) antara sesama individu.

d. Talking dapat membantu guru mengetahui tingkat pemahaman siswa belajar matematika,

e. Aktivitas write dapat meningkatkan keterampilan berfikir dan menulis

\section{Langkah-langkah Pembelajaran}

Kooperatif Tipe Think Talk Write (TTW)

Langkah-langkah pembelajaran dengan tipe TTW menurut Yamin dan Ansari (2012:90) adalah sebagai berikut :

a. Guru membagi teks bacaan berupa Lembar Diskusi Siswa (LDS) yang memuat situasi masalah dan petunjuk serta prosedur pelaksanaannya,

b. Siswa membaca teks dan membuat catatan dari hasil bacaan secara individual untuk dibawa ke forum diskusi (think),

c. Siswa berinteraksi dan berkolaborasi dengan teman untuk membahas isi catatan (talk). Guru berperan sebagai mediator lingkungan belajar, siswa mengkontruksi sendiri pengetahuan sebagai hasil kolaborasi (write).

Lebih rinci dalam penelitian ini

langkah-langkah pembelajaran

Kooperatif Tipe Think Talk Write (TTW) yang digunakan adalah:

a. Siswa dalam kelompok memperoleh BKS yang berbasis kemampuan komunikasi matematika yang berisi lembar kegiatan, masalah matematika, dan petunjuk pengerjaannya.

b. Siswa membaca dan mempelajari (think) BKS tersebut secara mandiri, kemudian membuat rencana penyelesaian 
masalah yang akan digunakan dalam menyelesaikan masalah tersebut.

c. Siswa mendiskusikan (talk) hasil pemikirannya tersebut dalam kelompok untuk mendapatkan kesepakatan dan menambah pemahaman mengenai cara menyelesaikan masalah matematis tersebut.

d. Dari hasil diskusi, siswa menuliskan (write) penyelesaian masalah yang dianggap benar.

e. Satu atau beberapa kelompok mewakili satu kelas mempresentasikan BKSnya, sedangkan kelompok yang lain diminta untuk memberi tanggapan.

f. Bersama-sama dengan guru, siswa membuat refleksi dan kesimpulan atas solusi penyelesaian masalah tersebut.

\section{H. Hipotesis Tindakan}

Berdasarkan kerangka berpikir diatas maka dirumuskan hipotesis sebagai berikut: Kemampuan Komunikasi Matematis Siswa Kelas XII MIPA SMA Negeri 1 Sakra dapat meningkat melalui Pembelajaran Kooperatif Tipe Think Talk Write (TTW).

\section{METODE PENELITIA}

$\mathbf{N}$

\section{A. Jenis Penelitian}

Penelitian ini merupakan penelitian tindakan kelas (classroom action research). Menurut Basrowi (2008:28), Penelitian tindakan dalam bidang pendidikan yang dilaksanakan dalam kawasan kelas dengan tujuan untuk memperbaiki dan meningkatkan kualitas pembelajaran. Secara singkat PTK dapat didefinisikan sebagai suatu bentuk penelaahan penelitian yang bersifat reflektif dengan melakukan tindakan-tindakan tertentu agar dapat memperbaiki dan meningkatkan praktik- praktik pembelajaran di kelas secara lebih professional.

B. Setting Penelitian

1. Tempat Penelitian

Penelitian tindakan kelas ini dilaksanakan di kelas XII MIPA SMA Negeri 1 Sakra.

2. Waktu Penelitian

Pelaksanaan Siklus I pada tanggal 18 sampai dengan 20 Oktober 2020 dan Pelaksanaan Siklus II pada tanggal 22 sampai dengan 20 Oktober 2020 semester ganjil tahun ajaran 2020/2021.

3. Siklus Penelitian

PTK ini dilaksanakan melalui dua siklus untuk menigkatkan kemampuan komunikasi matematis siswa kelas XII MIPA SMA Negeri 1 Sakra melalui pembelajaran kooperatif tipe Think Talk Write (TTW).

\section{Subjek Penelitian}

Subjek penelitian dalam penelitian ini yaitu siswa kelas XII MIPA SMA Negeri 1 Sakra dengan jumlah siswa 20 orang yang terdiri dari 11 siswa laki-laki dan 9 siswa perempuan. Aloisius Rabata Taburarusta Martagalasa sebagai peneliti sekaligus pengajar, sedangkan pengamat terdiri dari dua orang teman sejawat yaitu Lailatul Khodar dan Albert Widodo yang membantu peneliti merekam proses pembelajaran.

\section{Prosedur Penelitian}

Untuk memecahkan masalah penelitian diperlukan langkah yang tepat dalam penanganannya. Sesuai dengan jenis penelitian yang dipilih yaitu penelitian tindakan kelas (PTK) melalui pembelajaran kooperatif tipe Think Talk Write (TTW), maka pelaksanaan tindakan dilakukan dalam dua siklus. Setiap siklus terdiri atas dua pertemuan.

Dalam penelitian ini, peneliti menggunakan model siklus pelakasanaan yang dikembangkan oleh Kusamah dan Dwitagama (2009:44). 


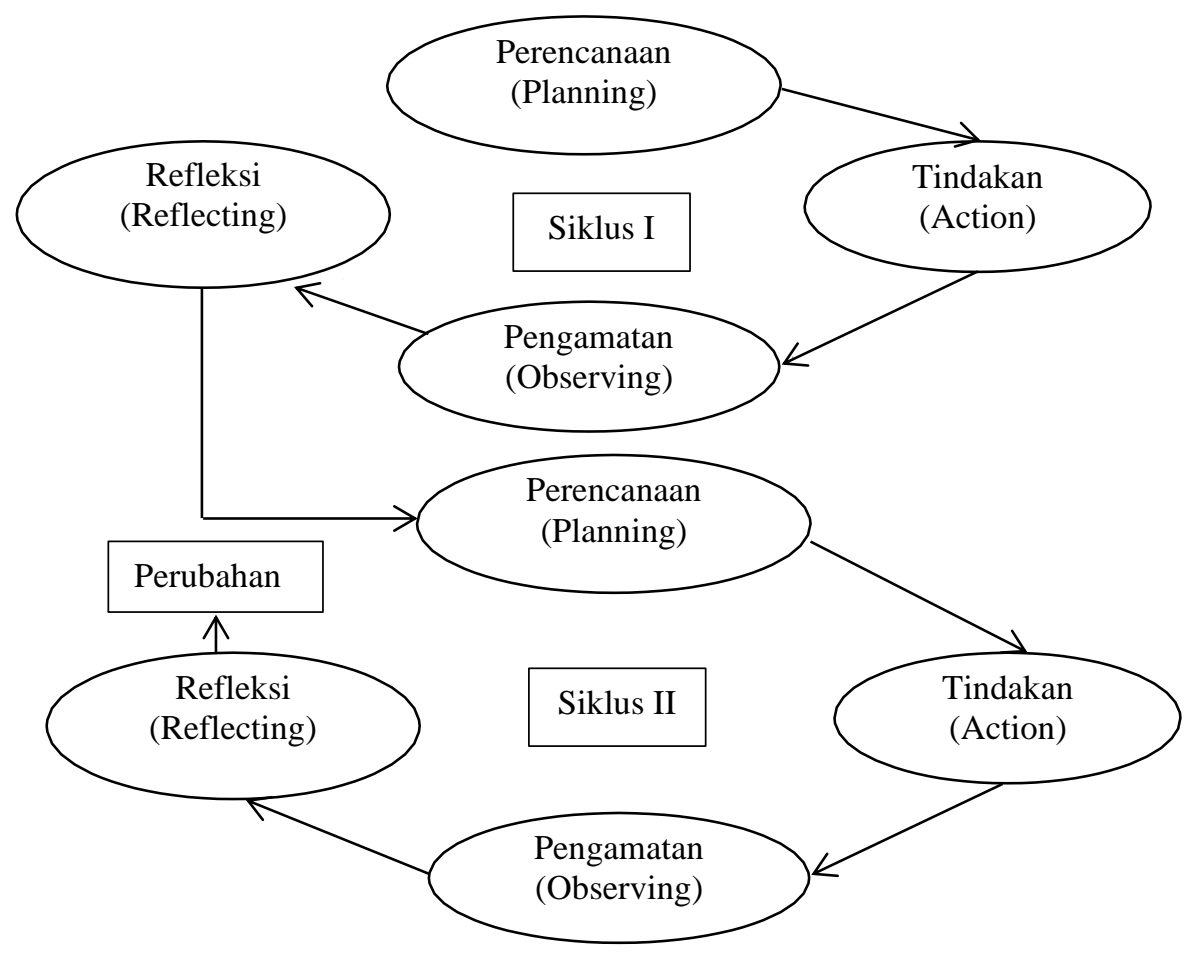

(Kusamah dan Dwitagama, 2009:44)

Penelitian Tindakan Kelas (PTK) menurut Wijaya Kusamah dan Dedi Dwitagama (2009:8-9) adalah penelitian yang dilakukan oleh guru dikelasnya sendiri dengan cara (1) merencanakan, (2) melaksanakan, (3) pengamatan, dan (4) merefleksikan tindakan secara kolaboratif dan partisifatif dengan tujuan memperbaiki kinerja sebagai guru, sehingga hasil belajar siswa dapat meningkat. Rincian tahapan kegiatan tersebut dapat diuraikan sebagai berikut:

\section{Siklus I}

a. Perencanaan

Dalam tahap perencanaan ini meliputi:

1) Membuat Rencana Perbaikan Pembelajaran (RPP) dengan mengacu pada indikator dan tujuan pembelajaran yang telah dirumuskan, serta sintaks model pembelajaran kooperatif tipe Think Talk Write (TTW) yang menitikberatkan pada pembelajaran yang dapat meningkatkan kemampuan komunikasi matematis siswa.

2) Menyusun BKS dengan materi turunan dan alat evaluasi pembelajaran.

3) Menyusun instrumen penelitian berupa tes kemampuan komunikasi matematis secara tertulis yang digunakan untuk mengukur kemampuan komunikasi matematis siswa secara tertulis.

4) Menyusun lembar observasi Kegiatan Belajar Mengajar (KBM) untuk mengamati kemampuan guru menerapkan pembelajaran koopertatif tipe Think Talk Write (TTW) dalam Kegiatan Belajar Mengajar (KBM), lembar observasi kemampuan komunikasi matematis siwa secara lisan tahap "talk" untuk mengamati kemampuan komunikasi matematis siswa secara lisan dan lembar catatan lapangan yang digunakan hal-hal yang menyimpang dan menghambat dari proses belajar mengajar. 
b. Tindakan

Dalam tahap tindakan ini, semua yang telah direncanakan dalam perencanaan dilakasanakan dalam Kegiatan Belajar Mengajar (KBM) di kelas sesuai dengan pembelajaran kooperatif tipe Think Talk Write (TTW). Langkah-langkah pembelajaran dalam kegiatan belajar mengajar sesuai dengan langkah-langkah dalam Rencana Perbaikan Pembelajaran (RPP) yang telah disusun dalam tahap perencanaan. Tindakan perbaikan yang dilakukan dalam penelitian ini adalah perbaikan pembelajaran dalam Kegiatan Belajar Mengajar (KBM) sesuai dengan sintak pembelajaran kooperatif tipe Think Talk Write (TTW) untuk meningkatkan kemampuan komunikasi matematis siswa.

c. Pengamatan

Dalam tahap pengamatan ini, para pengamat mengamati jalannya proses belajar mengajar dan kemampuan komunkasi matematis siswa. Hal yang diamati adalah kemampuan komunikasi metamatis siswa secara lisan dalam tahap talk atau diskusi dan kinerja guru dalam mengajar selama kegiatan belajar mengajar berlangsung. Pengamatan dilakukan oleh 2 orang pengamat (observer) yang memahami pembelajaran Kooperatif Tipe Think Talk Write (TTW). Dua observer tersebut mengamati pelaksanaan pembelajaran dengan menggunakan lembar observasi Kegiatan Belajar Mengajar (KBM), lembar observasi kemampuan komunikasi matematis siswa secara lisan tahap "talk" serta catatan lapangan yang telah dipersiapkan. Para observer mengamati dan mencatat segala sesuatu yang terjadi pada saat pembelajaran di kelas. Pengisian pengamatan ini sesuai dengan lembar observasi yang telah tersedia, namun apabila ada hal yang dalam lembar observasi tidak tersedia maka observer harus menulis di catatan lapangan. Catatan ini bertujuan untuk memberikan masukkan perbaikan pembelajaran guru pada siklus berikutnya. Setelah pengamatan selesai, peneliti dan observer merangkum hasil tes dan hasil observasi yang dilakukan untuk mempermudah dalam merefleksikan tindakan.

d. Refleksi

Berdasarkan hasil evaluasi pada siklus I, maka bersama pengamat membahas hasil penelitian terhadap pelaksanaan tindakan berdasarkan indikator yang telah ditetapkan sebelumnya. Bila ditemukan kendala dan permasalahan, maka peneliti mencoba sharing ide untuk mencari solusi pemecahan permasalahan-permasalahan tersebut, kemudian solusi-solusi tersebut akan dijadikan dasar dalam tahap perencanaan siklus berikutnya.

\section{Siklus II}

Secara garis besar, tahapan kerja siklus II sama dengan tahapan kerja siklus I. Rencana tindakan siklus II disusun berdasarkan hasil refleksi siklus I. Kegiatan-kegiatan yang dilakukan pada siklus II dimaksudkan sebagai penyempurnaan atau perbaikan terhadap pelaksanaan pembelajaran pada siklus I. Setelah itu dilakukan observasi dan refleksi.

\section{F. Metode Pengumpulan Data}

Data adalah hasil pencatatan peneliti, baik yang berupa fakta maupun angka (Arikunto, 2002:96). Dalam penelitian ini, metode pengumpulan data yang digunakan adalah melalui metode tes, metode observasi, dan catatan lapangan.

\section{Metode Tes}

Tes adalah serentetan pertanyaan atau latihan serta alat lain yang digunakan untuk mengukur keterampilan, pengetahuan, intelegensi, kemampuan atau bakat yang dimiliki oleh individu atau kelompok (Arikunto, 2002:127). Tes dalam penelitian ini digunakan untuk mengetahui data peningkatan kemampuan komunikasi matematika siswa secara tertulis. Penilaian dilakukan pada saat akhir pembelajaran setiap siklusnya untuk mengetahui kemampuan komunikasi matematis siswa secara tertulis.

\section{Metode Observasi}

Teknik Observasi digunakan untuk memperoleh data tentang kemampuan guru menerapkan pembelajaran kooperatif tipe Think Talk Write (TTW) dalam kegiatan 
belajar mengajar dan kemampuan komunikasi matematis siswa secara lisan pada tahap "talk". Instrumen yang digunakan berupa lembar observasi. Lembar observasi ini diisi oleh teman sejawat pada saat proses belajar mengajar berlangsung untuk mengetahui aktifitas guru (Peneliti) dan siswa.

3. Catatan Lapangan

untuk $\begin{gathered}\text { Catatan lapangan digunakan } \\ \text { mengumpulkan data di }\end{gathered}$ lapangan, mengetahui aktifitas yang terjadi selama kegiatan belajar mengajar. Catatan lapangan merupakan alat yang penting dalam penelitian pada waktu kegiatan berlangsung.

\section{H. Teknik Analisis Data}

Analisis data dalam penelitian ini adalah dengan menggunakan analisis deskriptif kualitatif, penelitian ini bertujuan untuk membuat gambaran (deskriptif) yang sistematis, faktual, dan akurat mengenai fakta-fakta yang terjadi dalam proses pembelajaran di kelas. Analisis data yang dilakukan dalam penelitian ini meliputi:

1. Analisis Data Hasil Tes Kemampuan Komunikasi Matematis Secara Tertulis Tabel 3.5. Tabel Penskoran Diadaptasi dari Pedoman Penskoran Soal- Soal Komunikasi Matematis yang dikembangkan Isrok'atun

\begin{tabular}{|c|c|c|c|c|}
\hline \multirow[b]{2}{*}{$\begin{array}{l}\text { No. } \\
\text { Soal }\end{array}$} & \multirow[b]{2}{*}{ Skor Maks } & \multicolumn{3}{|c|}{ Kriteria } \\
\hline & & Skor & $\begin{array}{l}\text { Menyatakan suatu Situasi } \\
\text { dengan Gambar dan Model } \\
\text { Matematika }\end{array}$ & $\begin{array}{c}\text { Menjelaskan Ide, } \\
\text { Situasi, dan Relasi } \\
\text { Matematika secara } \\
\text { Tertulis }\end{array}$ \\
\hline \multirow[t]{4}{*}{$1-3$} & \multirow[t]{4}{*}{3} & $\mathbf{0}$ & $\begin{array}{l}\text { Tidak membuat gambar/ } \\
\text { pemodelan matematika atau } \\
\text { membuat gambar/ pemodelan } \\
\text { Matematika tetapi salah. }\end{array}$ & $\begin{array}{l}\text { Tidak menjelaskan } \\
\text { ide, situasi, dan relasi } \\
\text { matematika secara } \\
\text { tertulis. }\end{array}$ \\
\hline & & 1 & $\begin{array}{l}\text { Membuat gambar (jika } \\
\text { mungkin)/model matematika } \\
\text { dari apa yang diketahui. }\end{array}$ & $\begin{array}{l}\text { Menjelaskan ide dan } \\
\text { situasi secara tertulis. }\end{array}$ \\
\hline & & 2 & $\begin{array}{l}\text { Membuat gambar (jika } \\
\text { mungkin)/model matematika } \\
\text { dari apa yang ditanyakan. }\end{array}$ & $\begin{array}{l}\text { Menjelaskan relasi } \\
\text { secara tertulis. }\end{array}$ \\
\hline & & 3 & $\begin{array}{l}\text { Membuat gambar (jika } \\
\text { mungkin)/model matematika } \\
\text { secara lengkap. }\end{array}$ & $\begin{array}{l}\text { Menjelaskan ide, } \\
\text { situasi, dan relasi } \\
\text { secara tertulis. }\end{array}$ \\
\hline $\begin{array}{l}\text { Total } \\
\text { Skor }\end{array}$ & $3 \times 3=9$ & & & \\
\hline
\end{tabular}

Setelah itu dilakukan perhitungan untuk Nilai Akhir sebagai berikut:

$$
N A=\frac{\text { Skor Perolehan Siswa }}{\text { Total Skor }} \times 100
$$

Keterangan:

$N A=$ nilai akhir siswa.

Analisis hasil tes kemampuan komunikasi matematis siswa secara tertulis dilakukan terhadap hasil tes kemampuan komunikasi matematis siswa secara tertulis siklus I dan siklus II. Pada hasil tes kemampua komunikasi matematis siswa secara tertulis siklus I hingga tes kemampuan komunikasi matematis siswa secara tertulis siklus II, nilai akhir kemampuan komunikasi matematis siswa secara tertulis yang diperoleh kemudian dikategorikan sesuai dengan kriteria menurut Arikunto (2008:245) yang telah dimodifikasi oleh penulis untuk membuat 
kesimpulan mengenai kemampuan komunikasi matematis siswa secara tertulis sesuai dengan kriteria tabel berikut:

Tabel 3.6. Kriteria Nilai Akhir Kemampuan Komunikasi Matematis Siswa dimodifikasi penulis.

\begin{tabular}{|c|c|}
\hline Kriteria & Kategori \\
\hline $80-100$ & Sangat Baik \\
\hline $60-79$ & Baik \\
\hline $40-59$ & Cukup Baik \\
\hline$N A \leq 39$ & Kurang Baik \\
\hline
\end{tabular}

Kemudian dihitung jumlah siswa yang telah mencapai kriteria keberhasilan yaitu minimal berada pada kategori baik dalam masingmasing siklus yang dinyatakan dengan Selanjutnya dihitun

siswa yang telah mencapai kriteria keberhasilan masing-

persentase untuk

masing siklus dengan rumus:

$$
\text { pst }=\frac{\sum T}{N} \times 100 \%
$$

Keterangan:

pst = persentase jumlah siswa yang mencapai kriteria ketuntasan

$\sum T=$ jumlah siswa yang mencapai kriteria ketuntasan

$N \quad=$ jumlah siswa

Data yang diperoleh selama penelitian akan dijadikan dasar untuk pelaksanaan siklus berikutnya. Kelas dikatakan tuntas dalam pembelajaran apabila persentase jumlah siswa yang minimal berada pada kategori baik mencapai $\geq 75 \%$ dari jumlah seluruh siswa yang tuntas.

\section{Analisis Data Hasil Observasi Kegiatan Belajar Mengajar (KBM)}

Dari hasil lembar observasi Kegiatan Belajar Mengajar (KBM) kemudian dianilisis tingkat keterlaksanaan proses belajar mengajar dengan menggunakan rumus:

$$
\begin{gathered}
S R O_{n}=\frac{\sum s k o r}{J B} \\
S R=\frac{\sum S R O_{n}}{n}
\end{gathered}
$$

Keterangan:

$\mathrm{SRO}_{\mathrm{n}}=$ skor rata-rata observer ke-n

$\sum$ skor $=$ skor perolehan JB

$=$ jumlah butir $\mathrm{SR}=$

skor rata-rata

$\mathrm{n} \quad=$ jumlah pengamat

karena PTK dalam penelitian ini dalam satu siklus terdiri dari 2 pertemuan, maka skor rata-rata total (SRT) setia siklus dihitung dengan rumus.

Keterangan:

SR $1=$ skor rata-rata pertemuan 1

$$
S R T=\frac{S R_{1}+S R_{2}}{2}
$$

$\mathrm{SR} 2=$ skor rata-rata pertemuan 2

kriteria keberhasilan pelaksanaan pembelajaran (Purbayanti, 2007:65), yaitu: 
Tabel 3.7. Kriteria Keberhasilan Pelaksanaan Pembelajaran

\begin{tabular}{|c|c|}
\hline Kriteria & Kategori \\
\hline $1,00<\mathrm{SRT} \leq 1,75$ & Tidak Baik \\
\hline $1,75<\mathrm{SRT} \leq 2,50$ & Cukup Baik \\
\hline $2,50<\mathrm{SRT} \leq 3,25$ & Baik \\
\hline $2,25<\mathrm{SRT} \leq 4,00$ & Sangat Baik \\
\hline
\end{tabular}

\section{Analisis Data Hasil Observasi Kemampuan Komunikasi Matematis secara lisan.}

Dari hasil observasi kemampuan komunikasi matematis siswa secara lisan kemudian dianalisis setiap aspek kemampuan komunikasi matematis siswa yang diamati dengan rumus:

$$
\begin{gathered}
S R O_{n}=\frac{\sum s k o r}{J B} \\
S R=\frac{\sum S R O_{n}}{n}
\end{gathered}
$$

Keterangan:

$\mathrm{SRO}_{\mathrm{n}}=$ skor rata-rata observer ke-n

$\sum$ skor $=$ skor perolehan JB $=$ jumlah

butir SR = skor rata-rata

$\mathrm{n} \quad=$ jumlah pengamat

karena PTK dalam penelitian ini dalam satu siklus terdiri dari 2 pertemuan, maka skor rata-rata total (SRT) setia siklus dihitung dengan

rumus:

$$
S R T=\frac{S R_{1}+S R_{2}}{2}
$$

Keterangan:

SR $1=$ skor rata-rata pertemuan 1

$\mathrm{SR} 2=$ skor rata-rata pertemuan 2

Kriteria kemampuan komunikasi matematika siswa, yaitu:

Tabel 3.8. Kriteria Kemampuan Komunikasi Matematika Siswa Secara Lisan.

\begin{tabular}{|c|c|}
\hline Kriteria & Kategori \\
\hline $1,00<$ SRT $\leq 1,75$ & Tidak Baik \\
\hline $1,75<$ SRT $\leq 2,50$ & Cukup Baik \\
\hline $2,50<$ SRT $\leq 3,25$ & Baik \\
\hline $2,25<$ SRT $\leq 4,00$ & Sangat Baik \\
\hline
\end{tabular}

\section{Indikator Keberhasilan}

Indikator keberhasilan pada penelitian ini ditentukan sebagai berikut:

1. Kemampuan guru menerapkan pembelajaran kooperatif tipe Think Talk Write (TTW) dalam Kegiatan Belajar Mengajar minimum berada dalam kategori baik.

2. Kemampuan komunikasi matematis siswa secara lisan minimum berada dalam kategori baik.

3. Hasil tes kemampuan komunikasi matematis siswa secara tertulis minimum berada dalam kategori baik.

4. Jumlah persentase ketuntasan kemampuan komunikasi matematis siswa secara tertulis minimum berada dalam kategori baik sebesar $\geq 75 \%$. 


\section{HASIL PENELITIAN}

\section{Hasil Kemampuan Komunikasi Matematis Siswa Secara Tertulis}

Untuk mengukur kemampuan komunikasi matematis siswa secara tertulis menggunakan tes kemampuan komunikasi matematis yang dilakukan pada setiap akhir siklus. Hasil tes tersebut dapat dilihat pada tabel 5.2 berikut :

Tabel 5.2. Perbandingan Hasil Tes Kemampuan Komunikasi Matematis Secara Tertulis Siklus I dan Siklus II

\begin{tabular}{|l|c|c|}
\hline \multicolumn{1}{|c|}{ Analisis } & Siklus I & Siklus II \\
\hline Hasil rata-rata tes & 58,64 & 68,75 \\
\hline Jumlah siswa yang tuntas & 5 & 10 \\
\hline Jumlah siswa yang tidak tuntas & 13 & 6 \\
\hline Jumlah siswa yang tidak mengikuti tes & 2 & 4 \\
\hline Jumlah siswa mengikuti tes & 18 & 16 \\
\hline Persentase ketuntasan kelas & $27,78 \%$ & $62,50 \%$ \\
\hline
\end{tabular}

Berdasarkan tabel 5.2 diatas, dapat dilihat bahwa nilai rata-rata tes siklus I sebesar 58.64 dan jumlah siswa yang tuntas sebanyak 5 siswa dengan persentase ketuntasan kelas sebesar 27,78\%. Hal ini menunjukkan bahwa indikator hasil tes kemampuan komunikasi matematis siswa pada siklus I belum mencapai kriteria yang diharapkan yaitu persentase jumlah siswa yang minimal berada pada kategori baik mencapai $\geq 75 \%$ dari jumlah seluruh siswa yang tuntas sehingga perlu diadakan siklus II. Hal tersebut terjadi karena siswa hanya menuliskan penjelasan ide dan situasi matematika secara tertulis namun tidak menuliskan penjelasan relasi matematika dalam menyelesaikan soal tes, dan sebaliknya siswa hanya menuliskan penjelasan relasi matematika tetapi tidak menuliskan idea dan situasi matematika dalam menyelesaikan soal tes.

Sedangkan bahwa nilai rata-rata tes siklus II sebesar 68,75 dan jumlah siswa yang tuntas sebanyak 10 siswa dengan persentase ketuntasan kelas sebesar 62,50\%. Hal ini menunjukkan bahwa indikator hasil tes kemampuan komunikasi matematis siswa pada siklus II belum mencapai kriteria yang diharapkan yaitu jumlah persentase siswa yang minimum berada pada kategori baik mencapai $\geq 75 \%$ dari jumlah seluruh siswa yang tuntas sehingga perlu diadakan siklus II. Hal tersebut terjadi karena siswa hanya menuliskan penjelasan ide dan situasi matematika secara tertulis namun tidak menuliskan penjelasan relasi matematika dalam menyelesaikan soal tes, dan sebaliknya siswa hanya menuliskan penjelasan relasi matematika tetapi tidak menuliskan idea dan situasi matematika dalam menyelesaikan soal tes. Selain itu karena siswa kurang maksimal dan konsentrasi siswa terbagi dengan persiapan ulangan harian mata pelajaran yang lain yang akan dilakukan pada hari yang sama. Memang tes ini dilakukan satu minggu sebelum pelaksanaan ujian akhir semester genap, sehingga pada hari-hari tersebut banyak ulangan harian dari guru mata pelajaran lain.

Selain itu, siswa masih kurang bisa menuliskan hal-hal yang diketahui, kurang teliti dalam menuliskan rumus dan penggunaan rumus, serta kurang teliti dalam perhitungan. Sehingga poin yang didapat dari soal tersebut tidak maksimal. Hal ini menyebabkan ketuntasan kelas belum mencapai indikator yang diharapkan.

Dari hasil tes siklus I dan siklus II dapat dilihat bahwa kemampuan siswa meningkat secara bertahap, artinya tidak bisa langsung meningkat secara instan. Untuk itu perlu adanya perbaikan lagi pada siklus selanjutnya agar indikator yang ditentukan dapat tercapai. Perbaikan tersebut diantaranya pengalokasian waktu RPP pada kegiatan inti yaitu mendiskusikan contoh soal dan pengerjaan latihan soal pada BKS untuk meningkatkan kemampuan komunikasi matematis siswa dan untuk lebih memahami materi yang diajarkan. 


\section{KESIMPULAN DAN SARAN}

\section{A. Kesimpulan}

Berdasarkan hasil tes, observasi

dan analisis data serta pembahasan dalam penelitian diperoleh:

1. Nilai rata-rata tes pada siklus I sebesar 58,64 dan siklus II sebesar 68,75.

Persentase ketuntasan kelas pada siklus I sebesar $27,78 \%$ dan siklus II sebesar $62,50 \%$. Hal ini menunjukkan bahwa kemampuan komunikasi matematis siswa secara tertulis mengalami peningkatan namun belum mencapai indikator yang ditentukan.

2. Skor rata-rata total kemampuan komunikasi matematis siswa secara lisan pada siklus I sebesar 2,43 dengan kategori cukup baik dan siklus II sebesar

2,98 dengan kategori baik. Hal ini menunjukkan bahwa kemampuan komunikasi matematis siswa secara lisan mengalami peningkatan dan sudah mencapai indikator yang ditentukan.

3. Skor rata-rata total hasil pengamatan KBM pada siklus I sebesar 2,70 dengan kategori baik dan siklus II sebesar 3,15 dengan kategori baik. Hal ini menunjukkan bahwa kemampuan guru dalam menerapkan pembelajaran kooperatif tipe think talk write (TTW) mengalami

peningkatan dan sudah

mencapai indikator

yang ditentukan.

4. Pembelajaran kooperatif tipe Think Talk Write (TTW) mampu meningkatkan kemampuan komunikasi matematis siswa namun peningkatannya belum optimal.

\section{B. Saran}

Salah satu tujuan pembelajaran matematika dalam kompetensi atau kecakapan matematika yang diharapkan dapat tercapai melalui pembelajaran matematika tertuang dalam Permendiknas no. 22 tentang standar isi pada poin empat yaitu mengkomunikasikan gagasan dengan simbol, tabel, diagram, atau media lain untuk memperjelas keadaan atau masalah. Sesuai dengan hal tersebut, komunikasi matematis merupakan salah satu kemampuan penting yang harus dikembangkan dalam diri peserta didik.
Usaha untuk dapat meningkatkan kemampuan komunikasi matematis adalah menerapkan pendekatan maupun model pembelajaran yang tepat bagi siswa. Berdasarkan hasil penelitian, pembelajaran kooperatif tipe Think Talk Write (TTW) merupakan salah satu alternatif pembelajaran yang mampu meningkatkan kemampuan komunikasi matematis siswa. Oleh karena itu, peneliti merekomendasikan saran sebagai berikut :

1. Peneliti lain yang ingin melakukan penelitian melalui Pembelajaran kooperatif tipe Think Talk Write (TTW) agar dapat lebih memperhatikan alokasi waktu yang digunakan untuk setiap tahap think, tahap talk, dan tahap write agar kegiatan belajar mengajar dengan Pembelajaran kooperatif tipe Think Talk Write (TTW) dapat berjalan lebih baik.

2. Siswa perlu mendapat bimbingan dari berbagai pihak untuk meningkatkan kesadaran akan pentingnya kemampuan komunikasi matematis.

3. Sebaiknya pembentukan kelompok memperhatikan karakteristik dan latar belakang siswa sehingga pembentukan kelompok adil dan tidak ada lagi dominasi karena hal ini akan berpengaruh pada saat diskusi kelompok.

4. Perlu memperhatikan pemilihan waktu penelitian yang baik untuk memperbaiki dan meningkatkan kemampuan komunikasi matematis siswa, karena tindakan memperbaiki ini tidak bisa dilakukan dengan waktu yang singkat.

\section{DAFTAR PUSTAKA}

Arends, Richard I. 2008. Learnig To Teach: Belajar Untuk Mengajar Edisi Ketujuh/Buku Dua. Yogyakarta: Pustaka Belajar.

Arikunto, Suhardjono, dan Supardi. 2009. Penelitian Tindakan Kelas. Jakarta: Bumi Aksara.

Arikunto, Suharsimi. 2008. Dasar-dasar Evaluasi Pendidikan (Edisi Revisi). Cetakan kedelapan. Jakarta: PT. Bumi Aksara. 
2003. Manajemen Penelitian. Jakarta: PT. Rineka Cipta

- 2002. Prosedur Penelitian Suatu Pendekatan Praktek. Jakarta: Rineka Cipta.

Basrowi, Suwandi. 2008. Prosedur Penelitian Tindakan Kelas. Anggota IKAPI: Ghalia Indonesia.

Departemen Pendidikan Nasional. 2006. Peraturan Menteri Pendidikan Nasional No. 22, 23, 24. Jakarta: Depdiknas.

Effendy, Onong Uchjana. 1984. Ilmu Komunikasi : Teori dan Praktek. Bandung: Remadja Karya Offset.

Gunawan, Ridwan Panji. 2013. Kemampuan Komunikasi Matematis.

http://proposalmatematika23.blogspo t.com/2013/02/kemampuan-

komunikasi-matematis.html (di akses tanggal 21 September 2020)

Huda, Miftahul. 2013. Model-model Pengajaran dan Pembelajaran. Yogyakarta: Pustaka Belajar

Isjoni. 2009. Cooperative Learning. Bandung: Alfabeta.

Isrok'atun. 2009. Pembelajaran Matematika Dengan Strategi Kooperatif Tipe Student Teams Achievement Divisions Untuk Meningkatkan Kemampuan Komunikasi Matematik Siswa. Pendidikan Dasar. Nomor $12 \quad$ Oktober 2009. http://file.upi.edu/Direktori/JURNAL /PENDIDIKAN_DASAR/Nomor_12 Oktober_2009/PEMBELAJARAN_ MATEMATIKA_DENGAN_STRA $\mathrm{T}$

EGI_KOOPERATIF_TIPE_STUDE NT_TEAMS_ACHIEVEMENT_DI V ISIONS UNTUK MENINGKATK AN KEMAMPUAN KOMUNIKA SI MATEMATIK SISWA.pdf (di akses 16 September 2020)

Juandi, Dadang. 2008. Pembuktian, Penalaran, dan Komunikasi Matematik.

http://file.upi.edu/Direktori/FPMIPA/ JUR._PEND._MATEMATIKA/1964
Kariani, Ribka. 2013. Pengaruh Pembelajaran Think-Talk-Write (TTW) Terhadap Kemampuan Komunikasi Matematik Dan Sikap Positif Siswa Terhadap Matematika. Tesis. Medan: Pendidikan Matematika Universitas Negeri Medan.

http://digilib.unimed.ac.id/public/UN IMED-Master-29635-

8106172047\%20Bab\%20V.pdf. $\quad$ Diakses pada 22 Januari 2015.

Kusumah, Wijaya dan Dwitagama, Dedi. 2009. Mengenal Penelitian Tindakan Kelas. Jakarta: PT. Indeks Permata Puri Media

Lie, Anita. 2004. Cooperative Learning: Mempraktikan Cooperative Learning di Ruang-Ruang Kelas. Jakarta: Grasindo

Moekijat. 1993. Teori Komunikasi. Bandung: Mandar Maju

Muslich, Masnur. 2013. Melaksanakan PTK (Penelitian Tindakan Kelas) Itu Mudah. Jakarta: Bumi Aksara

Nugroho, Prasetya Adhi. 2011. Meningkatkan Kemampuan Komunikasi Dan Pemecahan Masalah Matematika Siswa Smp Melalui Model Pembelajaran Kooperatif Tipe Think-Talk-Write (TTW). Skripsi. Yogyakarta: Jurusan Pendidikan Matematika FMIPA $U N Y$.

http://eprints.uny.ac.id/2119/1/SKRI

PSI nyong.pdf. (dikases 6 Sepetember 2020)

Purbayanti, Endang. 2007. Strategi Mengaktualisasikan Kecakapan Siswa Berpikir Kritis Dalam Memecahkan Masalah Matematika Denan Menggunakan Model Pembelajaran Berbasis Masalah. Skripsi tidak dipublikasikan. Madiun: Universitas Katolik Widya Mandala Madiun.

Qohar, Aqr. 2006. Pengembangan Instrumen Komunikasi Matematis Untuk Siswa SMP. Lomba dan Seminar Matematika XIX. 
http://eprints.uny.ac.id/6968/1/Makal ah\%20Peserta\%204\%20-

\%20Abd.\%20Qohar2.pdf. (di akses tanggal 22 September 2020)

Robbins, Stephen P.; Judge, Timothy A. 2008. Perilaku Organisasi Buku 1, Jakarta: Salemba Empat

Sanjaya, Wina. 2009. Penelitian Tindakan Kelas. Jakarta: Kencana Prenada Group.

Sari, Tri Novita. 2011. Upaya Meningkatkan Aktifitas dan Prestasi Belajar Matematika Siswa dengan Menggunakan Model Pembelajaran Kooperatif Tipe Numbered Heads Together (NHT). Skripsi tidak dipublikasikan. Madiun: Universitas Katolik Widya Mandala Madiun.

Slavin, Robert E. 2013. Cooperative Learning: Teori, Riset dan Praktik. Bandung: Nusa Media.

Suhaedi, Dedi. 2012. Peningkatan Kemampuan Komunikasi Matematis Siswa SMP Melalui Pendekatan Pendidikan Matematika Realistik. Seminar Nasional Matematika dan Pendidikan Matematika FMIPA UNY, Yogyakarta, 10 November 2012.

http://eprints.uny.ac.id/7593/1/P\%20 -\%2020.pdf (di akses 22 September 2020)

Sumarmo, Utari. 2006. Pembelajaran Keterampilan Membaca Matematika Pada Siswa Sekolah Menengah. Artikel FPMIPA UPI, Desember 2006.

https://www.academia.edu/4609768/ Sumarmo_Pembelajaran_Keterampil a
n_Membaca_Matematika_pada_Sisw a_Sekolah_Menengah (Di Akses September 2020).

Suprijono, Agus. 2013. Cooperative Learning : Teori dan Aplikasi PAIKEM. Yogyakarta: Pustaka Belajar.

Suroso. 2009. Penelitian Tindakan Kelas. Yogyakarta: Paraton.

Umar, Wahid. 2012. Membangun Kemampuan Komunikasi Matematis Dalam Pembelajaran Matematika. Infinity Jurnal Ilmiah Program Studi Matematika STKIP Siliwangi Bandung, Vol 1, No.1, Februari 2012.

http://download.portalgaruda.org/arti cle.php?article $=133689 \& \mathrm{val}=5628 \& \mathrm{t}$ itle $=($ diakses 29 September 2020)\}

Wahyuni, Anik Puji. 2014. Pengaruh Terhadap Kemampuan Komunikasi Matematik Siswa Kelas VII SMP. Skripsi tidak dipublikasikan. Madiun : Universitas Katolik Widya Mandala Madiun

Yamin, Martinis \& Bansu I. Ansari. 2012. Taktik Mengembangkan Kemampuan Individual Siswa. Jakarta: Referensi.

Yulita, Elsi. 2014. Pengaruh Model Pembelajaran Kooperatif Tipe Think Talk Write (TTW) Terhadap Kemampuan Komunikasi Matematika. Jurnal Pembelajaran MIPA. Volume 1 Nomor 1. (dalam http://ojs.stainbatusangkar.ac.id/inde x.php/edusainstika/article/viewFile/2 $4 \underline{8 / 240}$ ). Diakses pada 22 September 2020 . 